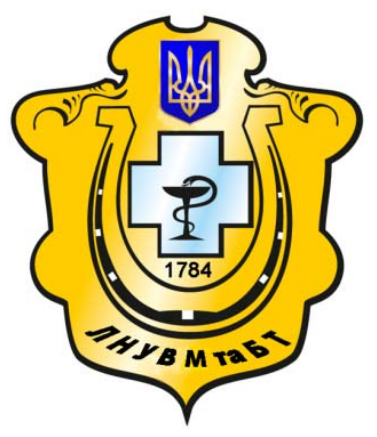

Науковий вісник Львівського національного університету ветеринарної медицини та біотехнологій імені С.3. Гжицького

Scientific Messenger of Lviv National University of Veterinary Medicine and Biotechnologies named after S.Z. Gzhytskyj

doi:10.15421/nvlvet7116

ISSN 2413-5550 print

ISSN 2518-1327 online

$\underline{\text { http://nvlvet.com.ua/ }}$

\title{
УДК 619:615.5
}

\section{Морфофункціональна характеристика печінки за визначення кумулятивних властивостей фітопрепарату «Щитник»}

\author{
Ж.М. Періг \\ jeannakuzjo@mail.ru
}

Державний науково-дослідний контрольний інститут ветеринарних препаратів та кормових добавок, вул. Донецька, 11, Львів, 79019, Украӥна;

В статті представлено результати дослідження впливу препарату «Щитник», у вигляді сухого екстракту, отриманого з кореневища папороті чоловічої (Rhizoma Dryopteris filix-mas, родини багатоніжкових - Polyродіaceae), на коефіцієнти маси внутрішніх органів, окремі біохімічні показники крові та морфологічну структуру печінки щурів за умов кумулячії.

Для визначення кумулятивних властивостей препарату «Щитник» використали метод-тест «субхронічної токсичності». Дослід проведено на 18 білих щурах, 2-місячного віку, масою тіла 140 - 160 г, з яких сформували дві групи тварин-аналогів: I - контрольна, II - дослідна (по 9 тварин у кожній). Для введення препарат розчиняли в пропіленгліколі $з$ водою у співвідноченні 1:1. Щурам дослідної групи препарат уводили перорально, щодобово, починаючи з дози 1300 мг/кг (що становить $1 / 10 D L_{50}$ ), з подальщим збільшенням дози в 1,5 рази кожні 4 доби. Тваринам контрольної групи вводили розчинник.

Встановлено, щяо введення щурам нового протипаразитарного препарату «Щитник», протягом 24 діб поспіль у сумарній дозі 36196,9 мг/кг викликало збільшення коефіиієнтів маси печінки, підвищення активності лужної фосфатази, трансаміназ у сироватці крові, в порівнянні з контролем, ще гістологічно підтверджувалося дистрофічно-некротичними змінами в паренхімі печінки, які характеризувалися розширенням центральних вен і внутрішньо-часточкових капілярів, каріорексисом, каріолізисом, зернистістю ицитоплазми гепатоцитів.

Ключові слова: щцитник, кумуляиія, білі щури, патоморфологічні зміни, трансамінази, лужна фосфатаза.

\section{Морфофункциональная характеристика печени при определении кумулятивных свойств фитопрепарата «Щитник»}

\author{
Ж.Н. Периг \\ jeannakuzjo@mail.ru
}

Государственный научно-исследовательский контрольный институт ветеринарных препаратов и кормовых добавок, ул. Донецкая, 11, г. Львов, 79019, Украина;

\begin{abstract}
В статье представлены результаты исследования влияния препарата «Щитник» в виде сухого экстракта, полученного из корневища папоротника мужского (Rhizoта Dryopteris filix-mas, порядок многоножковые -Polyродіасеае), на коэффициенты массы внутренних органов, отдельные биохимические показатели крови и морфологическую структуру печени крыс в условиях кумуляиии.

Для определения кумулятивных свойств препарата «Щитник» использовали метод-тест «субхроническое токсичности». Опыт проведен на 18 белых крысах, 2-месячного возраста, массой тела 140 - 160 г, из которых сформировали две группы животных-аналогов: I - контрольная, II - опытная (по 9 животных в каждой). Для введения препарат растворяли в пропиленгликоле с водой в соотношении 1:1. Крысам опытной группы препарат вводили перорально, ежесуточно, начиная с дозы 1300 мг/кг (что составляет 1/10 DL $L_{50}$ ), с последующим увеличением дозы в 1,5 раза каждые 4 сутки. Животным контрольной группы вводили растворитель.
\end{abstract}

Citation:

Perig, G. (2016). Morph functional characteristic of liver by the definition of cumulative properties of phytopreparations «Shchytnyk». Scientific Messenger LNUVMBT named after S.Z. Gzhytskyj, 18, 3(71), 70-74. 
Установлено, что введение крысам нового противопаразитарного препарата «Щитник», в течение 24 суток подряд в суммарной дозе 36196,9 ма/ кг вызывало увеличение коэффициентов массы печени, повышение активности шелочной фосфатазы, трансаминаз в сыворотке крови по сравнению с контролем, что гистологически подтверждалось дистрофически-некротическими изменениями в паренхиме печени, характерным расширением центральных вен и внутреннедольковых капилляров, кариорексисом, кариолизисом, зернистостью ичитоплазмы гепатоцитов.

Ключевые слова: шчитник, кумулячия, белье крысы, патоморфологические изменения, трансаминазы, ичелочная фосфатаза.

\title{
Morph functional characteristic of liver by the definition of cumulative properties of phytopreparations «Shchytnyk»
}

\author{
G. Perig \\ jeannakuzjo@mail.ru

\begin{abstract}
State Scientific-Research Control Institute of Veterinary Medicinal Products and Feed Additives, Donetska Str., 11, Lviv 79019, Ukraine;
\end{abstract}

The article presents the results of study of the search influence of the preparation "Shchytnyk» in the form of dry extract got from the roots of masculine ferns (Rhizoma Dryopteris filix-mas, order of many-stems-Polypodiaceae), on the coefficients of the mass of internal organs, some biochemical parameters of blood and morphological structure of rat liver in conditions of cumulation.

To determine the cumulative properties of the preparation "Shchytnyk" was used test method «subchronical toxicity". The experiment was conducted on 18 white rats, 2 - months old, with body mass of 140 - 160g, which were formed into two groups of animals-analogues: I - control, II - research (9 animals in each). To enter a drug it was dissolved in propylene glycol with water in a ratio of 1: 1. Rats of experimental drug were administered orally every day, starting with a dose of $1300 \mathrm{mg} / \mathrm{kg}$ (representing 1/10 $\left.D L_{50}\right)$, followed by increasing doses of 1.5 times every 4 days. The animals from the control group were injected with solvent.

The introduction of a new antiparasitis drug to rats «Shchytnyk» for 24 consecutive days at a total dose of $36196,9 \mathrm{mg} / \mathrm{kg}$ caused an increase coefficients in liver weight ratios, increased activity of alkaline phosphatase, liver transaminases in serum compared to control, that histologically confirmed dystrophic-necrotic changes in the parenchyma of the liver, and were characterized with the expansion of central venous and intra-lobular capillaries, cariorecsise, grit cytoplasm of hepatocytes.

Key words: Shchytnyk, cumulation, white rats, path morphological changes, liver transaminases, alkaline phosphatase.

\section{Вступ}

Будь-яка хімічна речовина, незалежно від надходження та нагромадження, потрапивши в організм не може проминути органи, зокрема печінку, яка відповідає за дезінтоксикаційну функцію, оскільки містить основні ензимні системи, що здійснюють біотрансформацію і дезінтоксикацію як чужорідних, так і властивих організму сполук. Виконуючи головну роль в обміні речовин та зв'язуючи портальне i загальне кола кровообігу, печінка знешкоджує токсичні продукти, які надходять в організм та утворюються в процесі травлення. Тому вона раніше за інші органи реагує на дію зовнішніх і внутрішніх несприятливих факторів (Fisher, 1961; Loginov and Aruin, 1985; Madej, 2002).

У системі протипаразитарних заходів застосовують препарати різноманітної природи, у котрих хіміко-фармацевтичні чинники займають головне місце. Проте постійне безсистемне нераціональне використання препаратів одних і тих же хімічних груп призводить до розвитку лікоопірності паразитів та швидкого поширення ареалу резистентних рас. У зв'язку з цим, важливе значення має застосування деяких рослин (і продуктів ïx переробки), як антигельмінтних засобів (Malyk, 2001). 3 цією метою розроблений новий протипаразитарний фітопрепарат «Щитник», що застосовується для профілактики i лікування цестодозів собак (Kocjumbas et al., 2011). В попередніх дослідженнях вивчалась токсичність нового препарату (Malyk et al., 2008), продовженням цих досліджень $є$ вивчення патоморфологічних змін в тканинах печінки за умов вивчення кумулятивних властивостей фітопрепарату «Щитник».

\section{Матеріал і методи досліджень}

Для визначення кумулятивних властивостей препарату «Щитник» використали метод-тест «субхронічної токсичності» за К.С. Лімом у модифікації К.К. Сидорова (Кocjumbas et al., 2007). Дослід проведено в умовах віварію ДНДКІ ветпрепаратів та кормових добавок на 18 білих щурах, 2-місячного віку, масою тіла 140 - 160 г, з яких сформували дві групи тварин-аналогів: I — контрольна, II — дослідна (по 9 тварин у кожній). Для введення препарат розчиняли в пропіленгліколі з водою (співвідношення 1:1). Щурам дослідної групи препарат уводили перорально, щодобово, починаючи 3 дози 1300 мг/кг (що становить 1/10 $\mathrm{DL}_{50}$ ), $з$ подальшим збільшенням дози в 1,5 рази кожні 4 доби. Тваринам контрольної групи вводили розчинник. На 24 добу введення, тварин кожної групи декапітували, за умов легкого ефірного наркозу, та відбирали кров для проведення біохімічних досліджень, проводили повний патологоанатомічний розтин 3 подальшим відбором матеріалу для гістологічного дослідження (Zon et al., 2009). Внутрішні органи зважували, вираховували коефіцієнти маси. Матеріал (шматочки внутрішніх органів і тканин) фіксували в $10 \%$ розчині нейтрального формаліну, 3 наступною заливкою в парафін. 3 парафінових блоків виготовляли гістозрізи товщиною 3-6 мкм на санному мікротомі МC-2. Гістозрізи фарбували гематоксиліном та 
еозином. Морфометрію тканин проводили з використанням морфометричної програми ДS-SOFT для мікроскопа OLYMPUS CX 41 та фотокамери OLYMPUS C-5050 (Merkulov, 1969).

У сироватці крові щурів визначали активність аланінамінотрансферази (АлАТ), аспартатамінотрансферази (АсАТ) за методом Райтмана-Френкеля та лужної фосфатази (ЛФ) - методом Кінга-Армстронга (за допомогою стандартних тест-наборів НВФ «Сімко», ФОП Даниш) (Vlizlo et al., 2012).

\section{Результати та їх обговорення}

Аналізуючи динаміку змін маси тіла дослідних тварин установлено, що препарат «Щитник» протягом 16 діб поспіль не впливав на масу тіла тварин, у порівнянні з контролем (табл. 1).

Виявлені динаміки приросту маси тварин узгоджуються зі зміною коефіцієнтів маси печінки (табл. 2). Встановлено, що коефіцієнт маси печінки дослідної групи був вірогідно більшим на $32,8 \%$ порівняно $з$ коефіцієнтом маси печінки тварин контрольної групи.

Таблиия 1

Динаміка маси тіла білих щурів при вивченні кумулятивних властивостей препарату «Щитник»

$(\mathbf{M} \pm \mathbf{m}, \mathbf{n}=\mathbf{9})$

\begin{tabular}{|l|l|l|l|l|l|l|c|}
\hline \multirow{1}{*}{ Групи } & \multicolumn{7}{|c|}{ Маса тіла (г) } \\
\cline { 2 - 9 } & $\begin{array}{c}\text { Початок } \\
\text { досліду }\end{array}$ & $\begin{array}{c}\text { На 4-у добу } \\
\text { введення }\end{array}$ & $\begin{array}{c}\text { На } 8 \text { добу } \\
\text { введення }\end{array}$ & $\begin{array}{c}\text { На } 12 \text { добу } \\
\text { введення }\end{array}$ & $\begin{array}{c}\text { На } 16 \text { добу } \\
\text { введення }\end{array}$ & $\begin{array}{c}\text { На } 20 \text { добу } \\
\text { введення }\end{array}$ & $\begin{array}{c}\text { На } 24 \text { добу } \\
\text { введення }\end{array}$ \\
\hline Котрольна & $150,7 \pm 4,02$ & $155,7 \pm 3,0$ & $163,5 \pm 2,8$ & $175,5 \pm 1,9$ & $181,7 \pm 1,7$ & $183,1 \pm 1,5$ & $183,3 \pm 1,1$ \\
\hline Дослідна & $151,3 \pm 3,07$ & $160,35 \pm 2,5$ & $169,4 \pm 2,2$ & $173,0 \pm 2,4$ & $179,2 \pm 1,3$ & $178,3 \pm 1,5$ & $176,6 \pm 1,7$ \\
\hline
\end{tabular}

Таблиия 2

Коефіціснти маси внутрішніх органів білих щурів за вивчення кумулятивних властивостей препара-

\begin{tabular}{|l|c|c|}
\multicolumn{2}{|c|}{ ту «Щитник» $(\mathbf{M} \pm \mathbf{m}, \mathbf{n}=\mathbf{9 )}$} \\
\hline Органи & Контроль & Дослід \\
\hline Печінка & $30,2 \pm 0,48$ & $40,1 \pm 1,23^{* * *}$ \\
\hline Легені & $12,0 \pm 3,18$ & $11,3 \pm 0,6$ \\
\hline Нирка права & $3,9 \pm 0,15$ & $3,9 \pm 0,09$ \\
\hline Нирка ліва & $3,6 \pm 0,17$ & $3,9 \pm 0,12$ \\
\hline Нирки обидві & $7,5 \pm 0,25$ & $7,9 \pm 0,17$ \\
\hline Серце & $4,06 \pm 0,17$ & $3,7 \pm 0,2$ \\
\hline Селезінка & $4,6 \pm 0,28$ & $4,9 \pm 0,27$ \\
\hline
\end{tabular}

Примітка: у цій $\mathrm{i}$ наступних таблицях ступінь вірогідності до контролю: *- $\mathrm{P}<0,05,{ }^{* *}-\mathrm{P}<0,01$

Аналіз отриманих даних щодо активності ензимів у сироватці крові дослідних щурів показав, що за умов кумуляції препарату «Щитник» встановлено тенденцію до збільшення активності амінотрансфераз. Про ступінь пошкодження плазматичних мембран гепатоцитів за введення препарату у сумарній кумулятивній дозі свідчили результати дослідження активності органоспецифічного ензиму лужної фосфатази (ЛФ). У кінці досліду активність вказаного ензиму у сироватці крові щурів II групи була вищою на 12,1\% $(\mathrm{p}<0,01)$, порівняно $з$ показниками у тварин контрольної групи (табл. 3).

Таблиия 3

Деякі біохімічні показники сироватки крові білих щурів за умов кумуляції препарату «Щитник»

\begin{tabular}{|l|c|c|}
\multicolumn{1}{c|}{$(\mathbf{M} \pm \mathbf{m}, \mathbf{n}=\mathbf{9})$} \\
\cline { 2 - 3 } & \multicolumn{2}{|c|}{ Група } \\
\hline Плказник & I & II \\
\hline АлАТ, мккат/л & $0,53 \pm 0,04$ & $0,59 \pm 0,01$ \\
\hline АсАТ, мккат/л & $0,84 \pm 0,01$ & $0,89 \pm 0,02$ \\
\hline ЛФ, нмоль $/$ с л & $659,0 \pm 10,50$ & $738,90 \pm 39,68^{* *}$ \\
\hline
\end{tabular}

При патолого-анатомічному розтині встановлено, що макроскопічно форма та величина печінки щурів контрольної і дослідних груп виглядала не зміненою. Більш виражена відмінність проявлялася при визначенні кольору органу. У контрольній групі тварин печінка однорідно зафарбована у темно-червоний колір, пружної консистенції, на розрізі структура збережена. У II групі тварин забарвлення печінки неоднорідне - вогнища світло-коричневого кольору чергуються зі світло-червоною посмугованістю, консистенція дещо дрябла, структура на розрізі згладжена.

За гістологічного дослідження печінки щурів контрольної групи спостерігали слабко виражене кровонаповнення центральних вен і судин тріад. У часточках відзначалося виразне радіальне розміщення сінусоїдних капілярів. Часточкова та балкова структура чітко виражена (рис. 1).

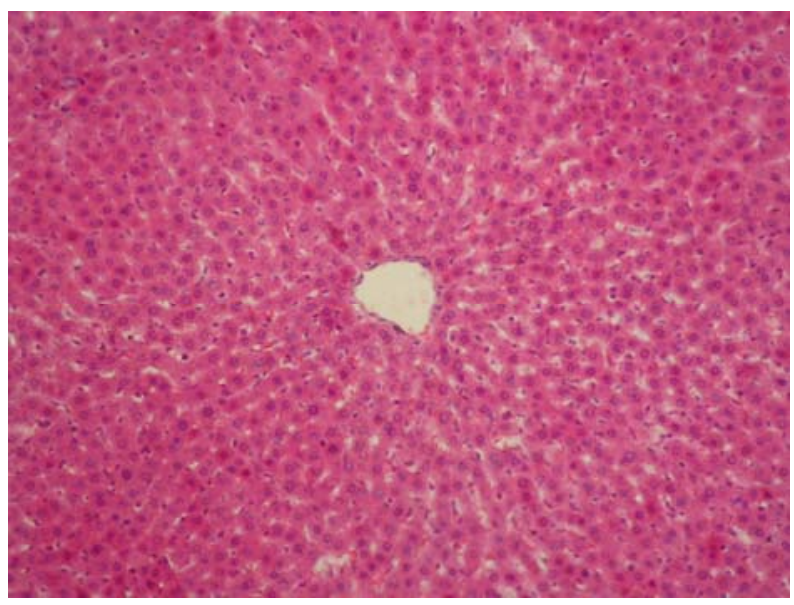

Рис.1. Печінка щурів I (контрольної групи). Балкова будова гепатоцитів збережена. Гематоксилін та еозин. Ок. 10, об. 10 
Клітини контуровані, з чіткими межами. Цитоплазма гепатоцитів однорідна, забарвлена у світлорожевий колір. У них чітко проглядались округлі, інтенсивно забарвлені ядра. Хроматин у більшості ядер був локалізований переважно на периферії, ближче до каріолеми. В окремих печінкових клітинах виявлялися по 2, а то й по 3 ядра, проте число таких клітин було незначним (рис. 2).

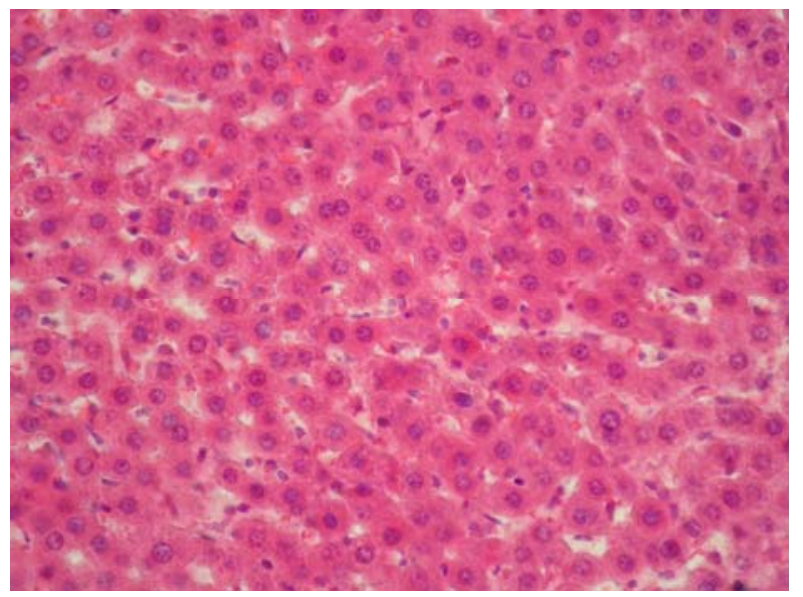

Рис.2. Гепатоцити чітко контуровані, цитоплазма однорідна, ядра збережені.

Гематоксилін та еозин. Ок. 10, об. 40

При гістологічному дослідженні печінки щурів II групи виявляли нерівномірне розміщення гепатоцитів в часточках, переважно окремими групами (дискомплексація) балкової структури, дифузне розширення внутрішньо-часточкових капілярів. Гепатоцити різної форми, контури згладжені, цитоплазма неоднорідно забарвлена, зерниста, окремі в стані каріорексису та каріолізису (рис. 3).

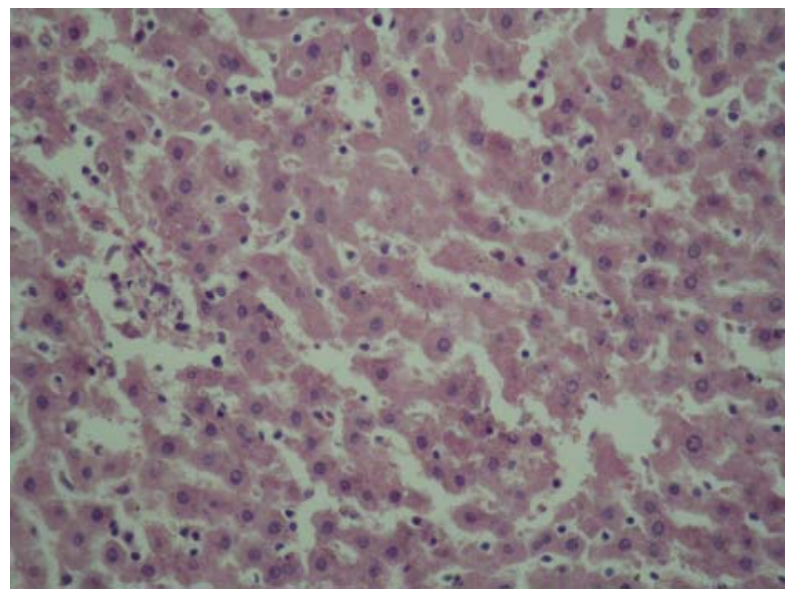

Рис. 3. Печінка щурів II групи. Дискомплексація балкової структури, контури гепатоцитів згладжені, цитоплазма неоднорідна, каріолізис. Гематоксилін та еозин. Ок. 10, об. 20

Особливості функції печінки, через яку проходять всі речовини, котрі всмоктуються із кишечника, обумовили і своєрідність ії кровообігу. По ворітній вені протікає 75\% загального об'єму крові, по печінковій артерії - 25\%, відплив крові проходить по печінкових венах. Розподіл крові відбувається так, що артеріальна кров тече в напрямку від зовнішнього до внутрішнього краю печінкової часточки, і тому в перилобулярній зоні гепатоцити прилягають до аферентних судин, а клітини в центролобулярній зоні знаходяться від них найдальше (Ivanov and Koval'skij, 1969).

Саме перилобулярно розміщені гепатоцити першими контактують із збагаченими поживними та антипоживними речовинами артеріальної крові i реагують при потраплянні токсичних речовин, що зумовлює розвиток дистрофічних змін (Zhunkejra, 2009).

Таким чином, макроскопічні та гістологічні зміни в печінці підтверджуються змінами показників активності амінотрансфераз та лужної фосфатази у сироватці крові щурів.

\section{Висновки}

Уведення щурам протипаразитарного препарату «Щитник» протягом 24 діб поспіль, отриманого 3 кореневища папороті чоловічої у сумарній дозі 36196,96 мг/кг, за умов вивчення кумулятивних властивостей, викликало зменшення маси тіла дослідних тварин, достовірне збільшення коефіцієнтів маси печінки i активності лужної фосфатази у сироватці крові, що гістологічно підтверджувалося дистрофічно-некротичними змінами в паренхімі печінки, які характеризувалися розширенням центральних вен і внутрішньо-часточкових капілярів, каріорексисом, каріолізисом, зернистістю цитоплазми гепатоцитів.

Перспективи подальших досліджень. Вивчення імунотоксичної дії препарату «Щитник».

\section{Бібліографічні посилання}

Madej, J.A. (2002). Patomorfologia hepatopatii polekowych. Medycyna Wet. 58(3), 163-168.

Loginov, A.S., Aruin, L.I. (1985). Klinicheskaja morfologija pecheni. M.: Medicina, 25-29 (in Russian).

Fisher, A. (1961). Fiziologija i jeksperimental'naja patologija pecheni. Budapesht: Akademija Kiodo, 104-139 (in Russian).

Malyk, O.G. (2001). Perspektyvy stvorennja ekologichno bezpechnyh likars'kyh zasobiv. Nauk. visnyk Uzhgorod. nac. u-tu. 9, 354-356 (in Ukrainian).

Kocjumbas, I.Ja., Perig, Zh.M., Homjak, R.V. (2011). Pat. 64274.-Ukrai'na. Protyparazytarnyj fitopreparat Shhytnyk - suhyj ekstrakt, otrymanyj sposobom luzhnogo gidrolizu iz korenevyshha paporoti cholovichoi'. Zajavnyk ta patentovlasnyk: DNDKI vetpreparativ ta kormovyh dobavok № u 201101040. Zajavleno 31.01.11.Opublikovano 09.02.11 (in Ukrainian).

Malyk, O.G., Pryhod'ko, Ju.O., Perig, Zh.M., Tishyn, O.L. (2008). Vyznachennja parametriv seredn'osmertel'nyh doz preparativ «Filiksan» ta 
«Shhytnyk», stvorenyh na osnovi korenevyshha paporoti. Nauk.-tehn. bjul. I-tu biol. t-n i DNDKI vetpreparativ ta kormovyh dobavok. 9(3), 226-230 (in Ukrainian).

Kocjumbas, I.Ja., Malyk, O.G., Paterega, I.P. (2006). Doklinichni doslidzhennja veterynarnyh likars'kyh zasobiv.. L'viv: Triada pljus (in Ukrainian).

Zon, G.A., Skrypka, M.V., Ivanovs'ka, L.B. (2009). Patologoanatomichnyj roztyn tvaryn. Donec'k (in Ukrainian).
Merkulov, G.A. (1969). Kurs patologogistologicheskoj tehniki. L.: Medicina (in Russian).

Vlizlo, V.V., Fedoruk, R.S., Ratych, I.B. (2012). Laboratorni metody doslidzhennja $\mathrm{u}$ biologii', tvarynnyctvi ta veterynarnij medycyni: dovidnyk. L'viv: Spolom (in Ukrainian).

Ivanov, I.F., Koval'skij, P.A. (1969). Citologija, gistologija, jembriologija. Moskva: Kolos, 104-139 (in Russian).

Zhunkejra, L.K. (2009). Gistologija: uchebnoe posobie.. Moskva: GOJeTAR-media, 405-410 (in Russian).

Стаття надійшла до редакиії 28.09.2016 